\section{Immunoreactivity for thymosin beta 4 and thymosin beta 10 in the adult rat oro-gastro- intestinal tract}

\author{
S. Nemolato, ${ }^{1}$ J. Ekstrom, ${ }^{2}$ T. Cabras, ${ }^{3}$ \\ C. Gerosa, ${ }^{1}$ D. Fanni, ${ }^{1}$ E. Di Felice, ${ }^{1}$ \\ A. Locci, ${ }^{1}$ I. Messana, ${ }^{3}$ M. Castagnola, ${ }^{4}$ \\ G. Faa' ${ }^{1}$
}

'Istituto di Anatomia Patologica, Dipartimento di Scienze Chirurgiche, PO S. Giovanni di Dio, Università di Cagliari, Italy;

2Division of Pharmacology, Institute of Neuroscience and Physiology, Sahlgrenska Academy, University of Gothenburg, Sweden; ${ }^{3}$ Dipartimento di Scienze della Vita e dell'Ambiente, Università di Cagliari, Italy;

${ }^{4}$ Istituto di Biochimica e Biochimica Clinica, Facoltà di Medicina, Università Cattolica di Roma, Italy

\section{Abstract}

Thymosin beta 4 (T $\beta 4)$ and thymosin beta 10 (T $\beta 10)$ are two members of the $\beta$-thymosin family, involved in multiple cellular activities in different organs in multiple animal species. Here we report the expression pattern of $\mathrm{T} \beta 4$ and $\mathrm{T} \beta 10$ in rat tissues, in the gut and in annexed glands. The two peptide were differently expressed: T 34 was absent in salivary glands whereas $\mathrm{T} \beta 10$ was expressed in parotid and in submandibular glands. T $\beta 4$ was mildly expressed in the tongue and in the oesophagus, where T $\beta 10$ was absent. A similar expression was found in the stomach, ileum and colon mucosa. In pancreas $\mathrm{T} \beta 4$ reactivity was restricted to the Langerhans islet cells; T $\beta 4$ was also detected in the exocrine cells. Both peptide were not expressed in liver cells. When the rat expression pattern in rat organs was compared to reactivity for $\mathrm{T} \beta 4$ and $\mathrm{T} \beta 10$ in humans, marked differences were found. Our data clearly indicate a species-specific expression of $\mathrm{T} \beta 4$ and $\mathrm{T} \beta 10$, characterized by the actual unpredictability of the expression of these peptides in different cells and tissues. The common high expression of $\mathrm{T} \beta 4$ in mast cells, both in humans and in rats, represents one of the few similarities between these two species.

\section{Introduction}

Beta thymosins are a versatile family of small peptides expressed in multiple tissues in mammals, that show many intracellular and extracellular activities. ${ }^{1,2}$ These peptides are named thymosins after their first isolation in the calf thymus. ${ }^{3}$ Fifteen highly homologous beta thymosin variants, containing 40 to 44 amino acid residues, have been described. ${ }^{4}$ Among beta thymosins, thymosin beta 4 $(\mathrm{T} \beta 4)^{5,6}$ and thymosin beta $10(\mathrm{~T} \beta 10)^{7}$ are the most abundant in human cells and rat tissues. ${ }^{8}$ During the years, beta thymosins have been detected inside of cells of different organs, ${ }^{9-14}$ as well as in human blood, ${ }^{15}$ in human saliva, ${ }^{16}$ in tears ${ }^{17}$ and in wound fluid after abdominal surgery. ${ }^{18}$ Many physiological properties and cellular functions are connected to T $\beta 4$ : Gactin-sequestering, ${ }^{1}$ promotion of cell migration, ${ }^{8}$ angiogenesis, ${ }^{9,19}$ stem cell differentiation, ${ }^{11}$ modulation of cytokines and chemokines. ${ }^{20}$ This peptide is also involved in lesion-induced neuroplasticity through microglia upregulation and it participates in the growth of neuronal processes. ${ }^{21}$ Therefore, the mRNA encoding for $\mathrm{T} \beta 4$ is expressed in mouse embryonic stem cells and in mesodermal-like cells (cardiac and skeletal muscle). ${ }^{22}$ Moreover, recent studies demonstrated a role of T $\beta 4$ in inducing the expression of the vascular endothelial growth factor (VEGF) in colon cancer cells in experimental models. ${ }^{19} \mathrm{~T} \beta 4$ also partecipates to the modulation of human colonic immune system ${ }^{23}$ probably through degranulation of mucosal mast cells. ${ }^{24}$ Contrasting results have been published on the role of $\mathrm{T} \beta 10$ in tumour progression. On one hand, T $\beta 10$ diminishes tumor growth, angiogenesis and proliferation ${ }^{25}$ and $\mathrm{T} \beta 10$ over-expression has been related to the increase of apoptosis in human ovarian cancer cells. ${ }^{25}$ On the other hand, T $\beta 10$ has been associated to the progression of papillary thyroid carcinoma ${ }^{26}$ and over-expression of the peptide has been observed in non-small cell lung cancer $^{27}$ and in pancreatic cancer. ${ }^{28}$ The recent report by our group of a strong expression for $\mathrm{T} \beta 10$ in the human salivary glands during development, ${ }^{29}$ induced us to better analyse the protein expression pattern for $\mathrm{T} \beta 10$ in the oro-gastro-intestinal tract in adult rats, in order to show if $\mathrm{T} \beta 10$ is expressed in the gastrointestinal tract in adulthood, and to compare the expression of this peptide with that reported in the human digestive tract and in annexed glands..$^{24,30,31}$ Moreover, rat tissues were immunostained for $\mathrm{T} \beta 4$, with the aim of verifying the reciprocal interactions of $\mathrm{T} \beta 4$ and $\mathrm{T} \beta 10$ in the oro-gastrointestinal tract.
Correspondence: Sonia Nemolato, Istituto di Anatomia Patologica, Dipartimento di Scienze Chirurgiche, PO S. Giovanni di Dio, Università di Cagliari, via Università 60, 09124 Cagliari, Italy. Tel. $+39.070 .6092370-$ Fax: +39.070 .657882 . E-mail: sonianemolato@libero.it

Key words: rats, thymosin beta 4 , thymosin beta 10 , immunohistochemistry, gastrointestinal tract.

Contributions: SN, GF, research design and manuscript writing; JE, CM, IM, critical review; TC, $\mathrm{CG}$, DF, EDF, AL, data analysis and research performing.

Conflicts of interest: the authors declare no conflicts of interest.

Acknowledgments: this work has been supported by "Fondazione Banco di Sardegna". The authors would like to thank Mr. Ignazio Ferru for the secretarial assistance. The authors also gratefully acknowledge the Sardinia Regional Government for the financial support (P.O.R. Sardegna F.S.E. Operational Programme of the Autonomous Region of Sardinia, European Social Fund 20072013 - Axis IV Human Resources, Objective 1.3, Line of Activity 1.3.1 Avviso di chiamata per il finanziamento di Assegni di Ricerca).

Received for publication: 21 January 2013. Accepted for publication: 5 April 2013.

This work is licensed under a Creative Commons Attribution NonCommercial 3.0 License (CC BYNC 3.0).

(C) Copyright S. Nemolato et al., 2013

Licensee PAGEPress, Italy

European Journal of Histochemistry 2013; 57:e17 doi:10.4081/ejh.2013.e17

\section{Materials and Methods}

In order to test $\mathrm{T} \beta 4$ and $\mathrm{T} \beta 10$ immunoreactivity in animals, 20 male wistar rats were the object of our study, divided into 10 male and 10 female. Tissues were obtained from each animal including samples from tongue, oesophagus, stomach, ileum, colon, parotid gland, submandibular gland, sublingual gland, liver and pancreas. All samples were fixed in $10 \%$ formalin, paraffin-embedded and routinely processed. Paraffin sections were immunostained with anti-T $\beta 4$ and anti-T $\beta 10$ antibodies, using the labeled streptavidin-biotin complex system (LSAB2, Dako) in a Dako Autostainer (Dako Cytomation, Carpinteria, CA, USA). Briefly, samples were deparaffinized, rehydrated, and endogenous peroxidase activity was quenced (30 $\mathrm{min})$ by $0.3 \%$ hydrogen peroxide in 
methanol. Slides were then subjected to heatinduced antigen retrieval by steaming unstained sections in a Target Retrieval Solution (Dako TRS pH 6.1) for 30 min. Slides were then incubated with $10 \%$ normal goat serum in phosphate-buffered saline (PBS) for 60 min to block non-specific binding, followed by incubation ( $60 \mathrm{~min}$ at room temperature) with a monoclonal anti-Thymosin Beta 4 antibody (Bachem-Peninsula Lab, San Carlos, CA, USA) and with a monoclonal anti-Thymosin Beta 10, respectively diluted 1:600 and 1:500 in the blocking solution. Slides were extensively washed with PBS containing $0.01 \%$ Triton X100 and incubated with a secondary reagent
Table 1. Immunoreactivity for thymosin beta $4(\mathrm{~T} \beta 4)$ and thymosin beta 10 (T/10) in rat tissues and humans.

\begin{tabular}{|c|c|c|c|c|}
\hline Organ & Tß4 Rat & T $\beta 10$ Rat & T $\beta 4$ Human & Tß10 Human \\
\hline Parothyd & - & +++ & + & + \\
\hline Submandibular gland & - & +++ & + & + \\
\hline Sublingual gland & - & - & + & + \\
\hline Tongue & + & - & + & ++ \\
\hline Oesofagus & - & - & + & - \\
\hline Stomach & + & + & + & - \\
\hline Ileum & + & + & + & - \\
\hline Colon & + & + & ++ & - \\
\hline Pancreas & + & ++ & ++ & + \\
\hline Liver & - & - & +++ & +++ \\
\hline
\end{tabular}

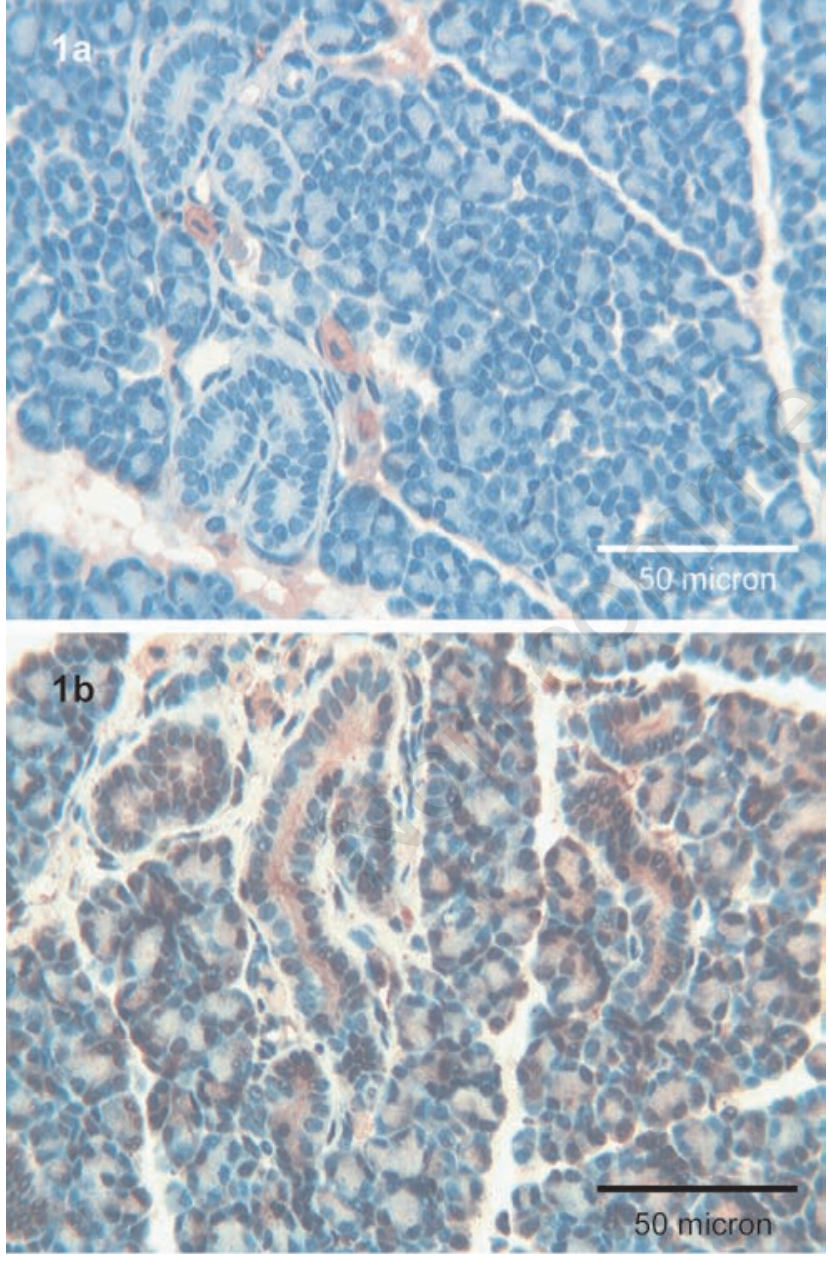

Figure 1. Parotid. a) No immunoreactivity for $\mathrm{T} \beta 4$ is detected in the parotid gland; scattered mast cells are strongly immunoreactive for the peptide; OM 250x. b) A granular and diffuse positivity for $\mathrm{T} \beta 10$ is observed in all the acinar structures; ductal cells show an apical and homogeneous reactivity for the peptide; $\mathrm{OM}$ 400x.
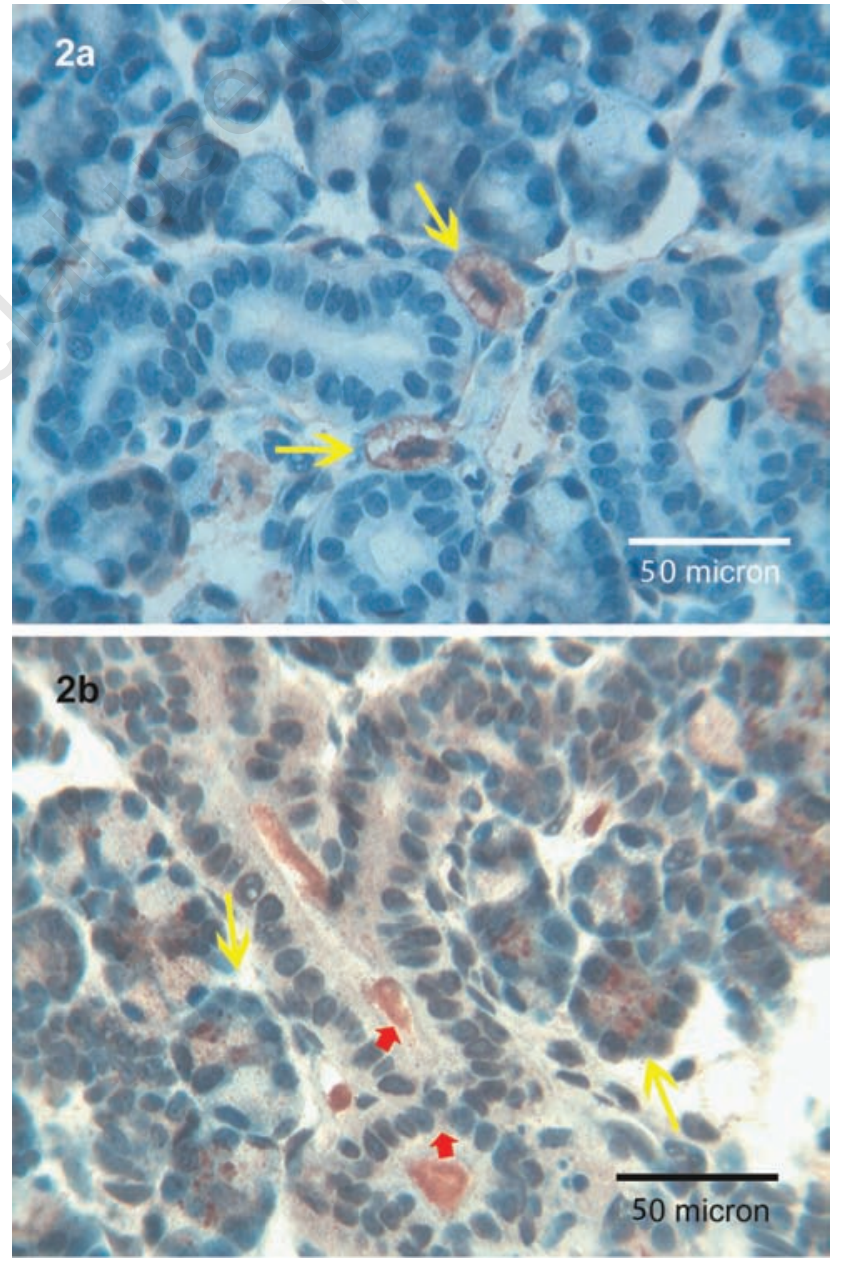

Figure 2. Submandibular glands. a) $T \beta 4$ is not expressed in the structures of the submandibular glands; only a fine positivity could be detectable in the surrounding stroma; mast cells show a strong granular cytoplasmic positivity (yellow arrows); OM 400x. b) Coarse granules of $T \beta 10$ are observed in the acini of the submandibular gland (yellow arrows); ductal cells present a fine cytoplasmic immunoreactivity for the peptide mainly localized in the lumen (red arrows); OM 400x. 
(En Vision kit) according with the manufacturer instructions (Dako, Glostrup, Denmark). Diaminobenzidine (DAB) was used as chromogen. After additional washes, colour was developed using the AEC reagent (Dako), sections were counterstained with Mayer's hematoxylin and mounted. Sections of reactive lymph nodes with $\mathrm{T} \beta 4$-immunoreactive histiocytes were utilized as a positive control. As a negative control, the same procedure was applied omitting the primary antibody.

\section{Results}

\section{Parotid}

Tß4 immunoreactivity was completely absent both in acini and in ducts (Figure 1a). $\mathrm{T} \beta 10$ was expressed both in acinar serous

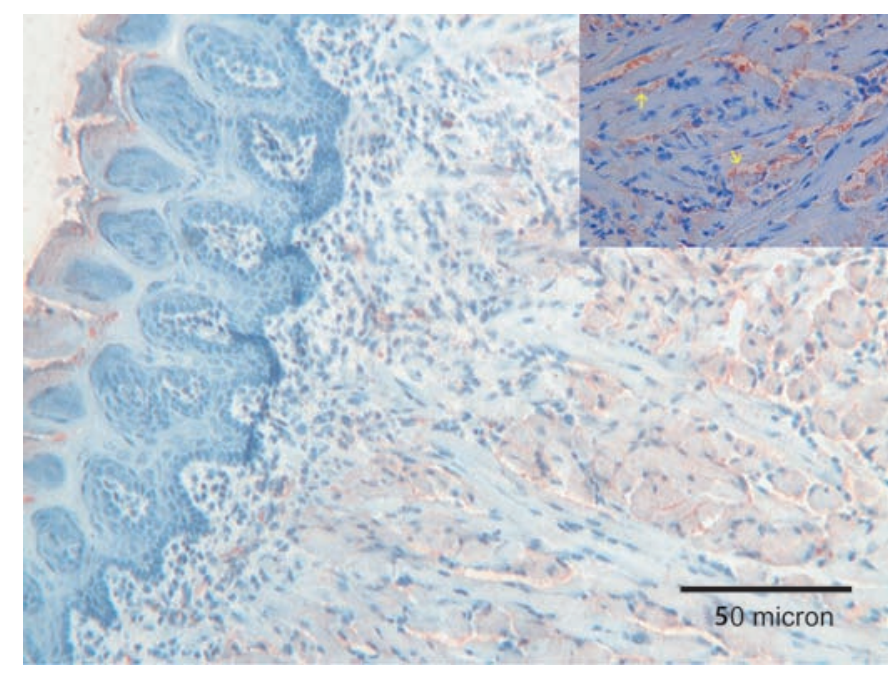

Figure 3. Tongue. A weak immunoreactivity for $\mathrm{T} \beta 4$ is observed only in the superficial layers of the tongue's epithelium; a weak immunostaining for the peptide was observed in cell membranes of muscle cells (see inset, yellow arrows); OM 250x.
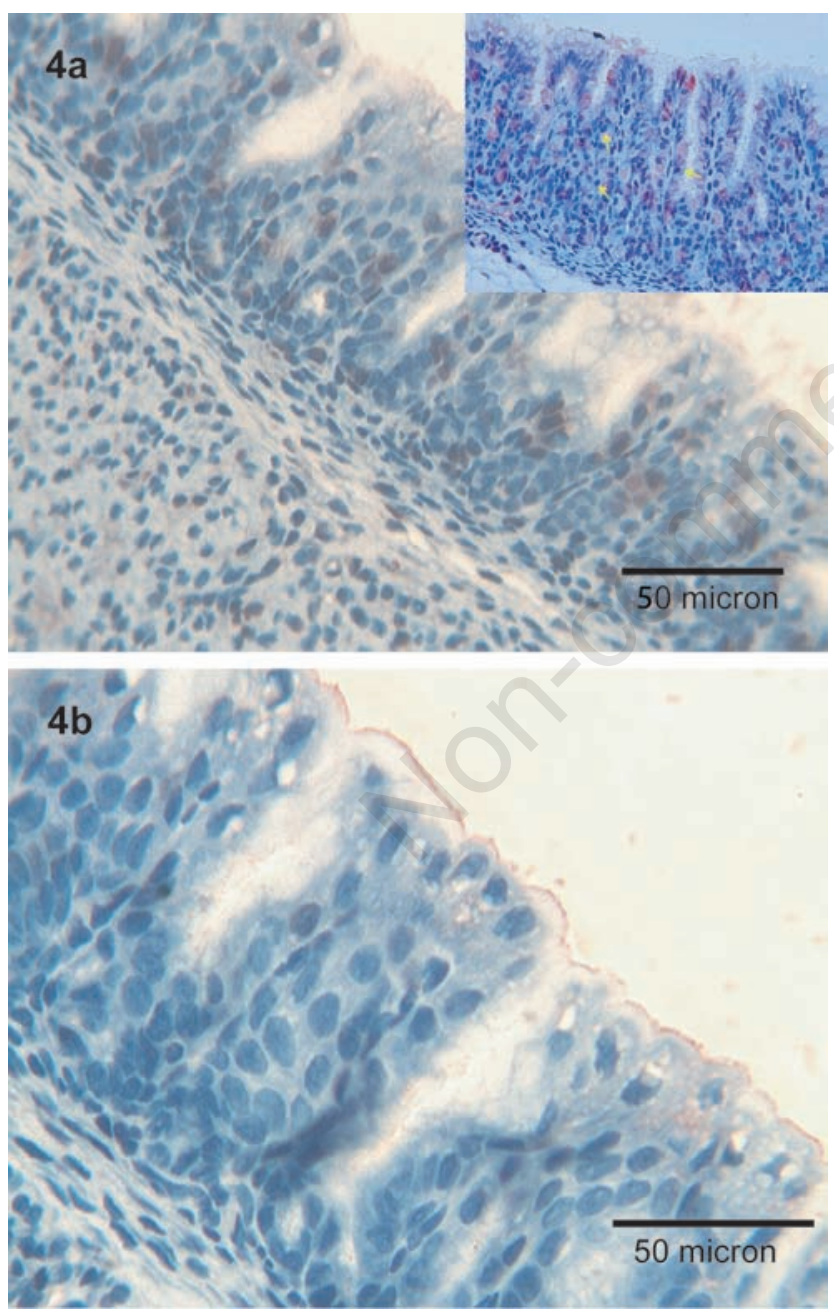

Figure 4. Stomach. a) Immunoreactivity for $\mathrm{T} \beta 4$ is expressed in scattered foveolar cells (see inset, yellow arrows) and in the luminal surface of the stomach; OM 400x. b) T $\beta 10$ is mainly localized in the luminal border of the foveolar cells of the stomach; OM 250x.
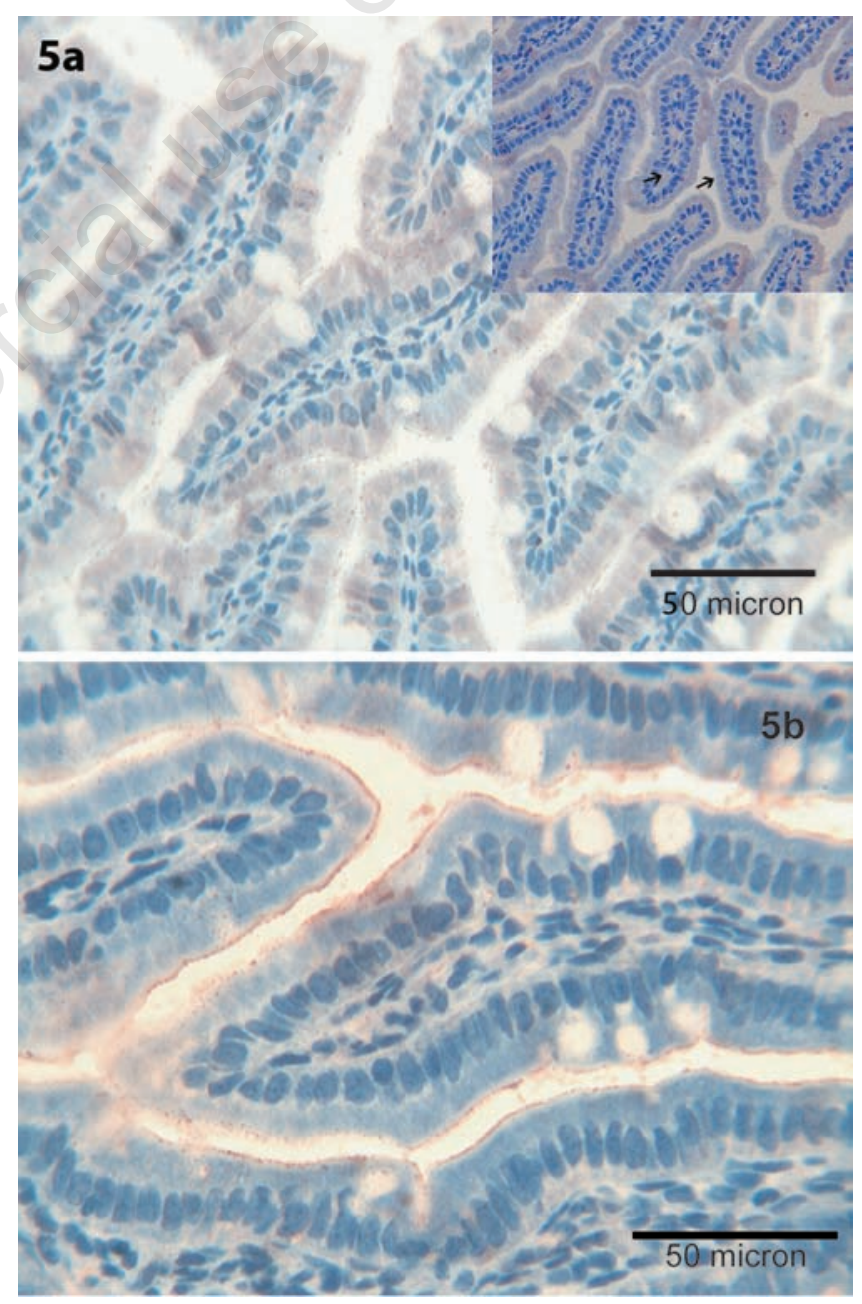

Figure 5. Ileum. a,b) $T \beta 4$ and $T \beta 10$ are detected in the surface epithelium of enterocytes covering the villi of the ileum (see inset, black arrows); OM 400x. 
cells, showing a granular pattern, as well as in ductal cells, in which a homogeneous cytoplasmic staining was detected (Figure 1b).

\section{Submandibular gland}

Fine T $\beta 4$-immunoreactive granules were observed in the periglandular stroma and in scattered mast cells, in the absence of any reactivity inside the salivary gland cells (Figure 2a). A strong reactivity for $\mathrm{T} \beta 10$ was observed in acinar serous cells, appearing as coarse granules and in mucous cells appearing as fine granules. The ducts show a homogeneous cytoplasmic staining and intraluminal granular deposits (Figure 2b).

\section{Sublingual glands}

No reactivity was detected for $\mathrm{T} \beta 4$ and for $\mathrm{T} \beta 10$.

\section{Tongue}

A mild immunoreactivity for $\mathrm{T} \beta 4$ was detected in the superficial layers of the stratified epithelium. Moreover, a weak immunostaining for the peptide was observed in muscle cells, mainly localized at the cell membrane (Figure $3)$. No reactivity for $\mathrm{T} \beta 10$ was found.

\section{Oesophagus}

Scattered T $\beta 4$-immunoreactive granules were detected inside the oesophageal lumen. No reactivity for $\mathrm{T} \beta 10$ was observed.

\section{Stomach}

Immunoreactivity for $\mathrm{T} \beta 4$ was restricted to scattered foveolar cells and to intraluminal granular deposits (Figure 4a). A similar expression pattern was observed for T $\beta 10$ (Figure $4 \mathrm{~b}$ ).

\section{Ileum}

$\mathrm{T} \beta 4$ was maily expressed in the cytoplasm of enterocytes covering ileal villi (Figure 5a). A similar pattern characterized immunoreactivity for $\mathrm{T} \beta 10$ (Figure $5 \mathrm{~b}$ ).

\section{Colon}

$\mathrm{T} \beta 4$ was maily expressed at the apical pole of enterocytes, and in fine granular deposits inside the intestinal lumen (Figure 6a), paralleling the expression pattern observed for $\mathrm{T} \beta 10$ (Figure 6b).

\section{Pancreas}

$\mathrm{T} \beta 4$ immunoreactivity was restricted to Langherans islets, in the absence of any significant immunostaining in the esocrine pancreas (Figure $7 \mathrm{a}$ ). On the contrary, T $\beta 10$ was
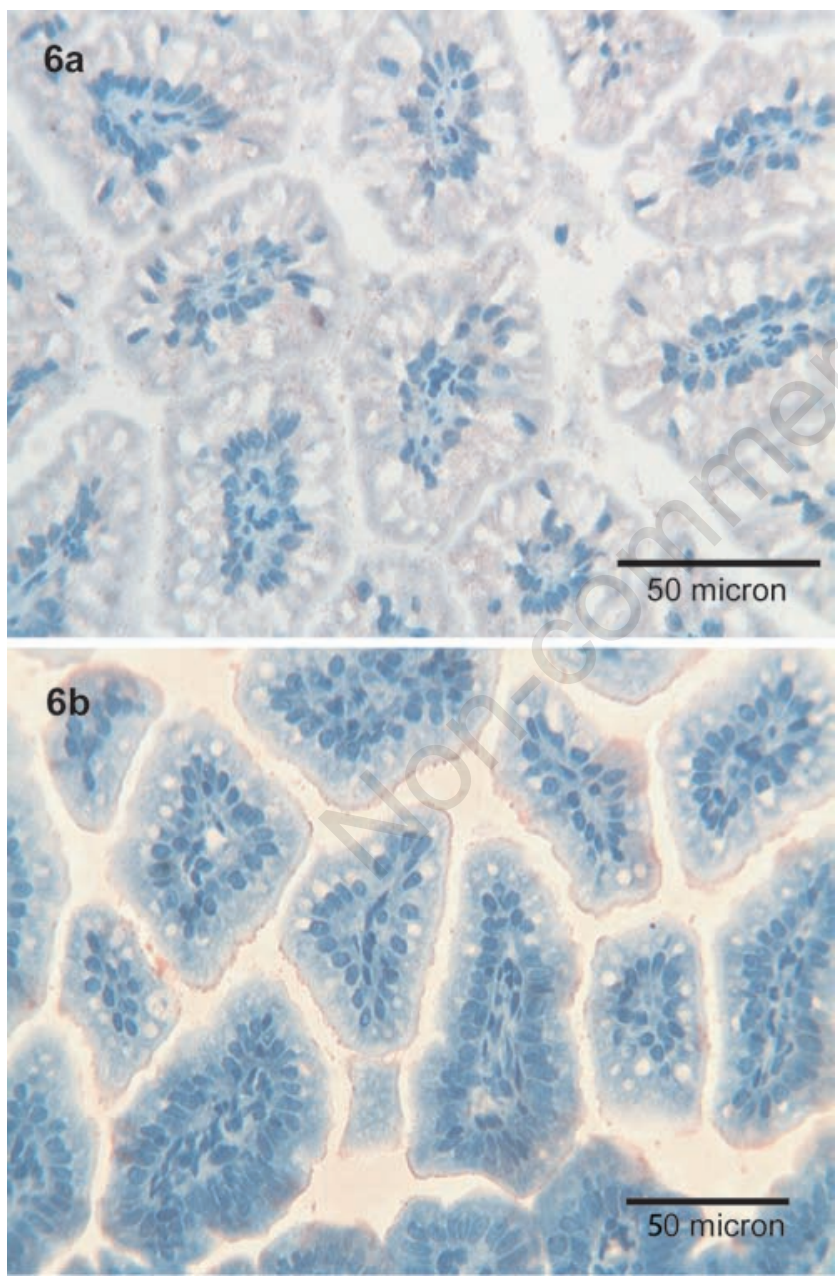

Figure 6. Colon. a,b) A fine granular positivity for $T \beta 4$ is observed in the brush border of the enterocytes in the surface epithelium of the colon and in the intestinal lumen; $T \beta 10$ parallels the immunoreactivity of T $\beta 4$; OM 400x.
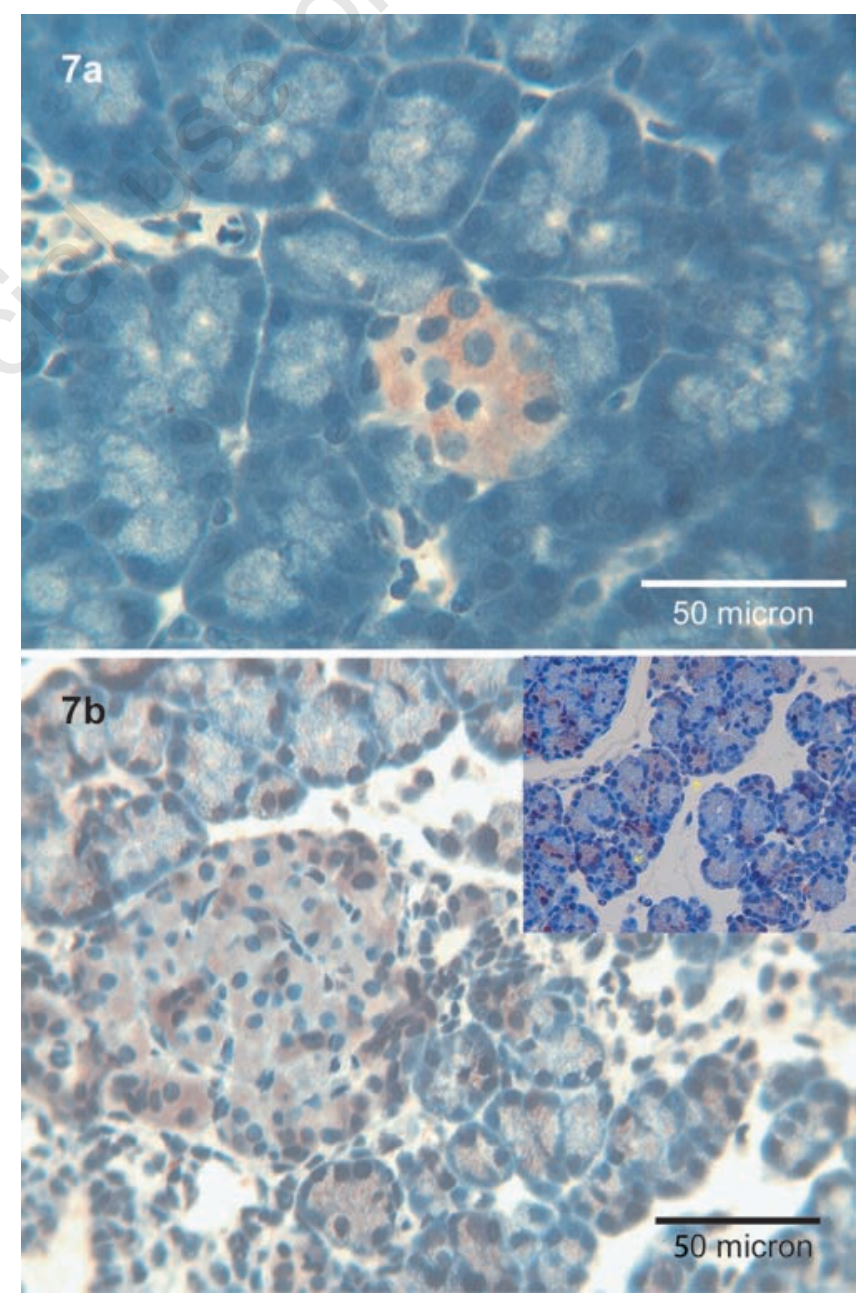

Figure 7. Pancreas. a) T $\beta 4$ is diffusely immunoexpressed in the islets of Langherans; no immunoreactivity is observed in the rest of pancreatic parenchima; OM 400x. b) Immunoreactivity for $T \beta 10$ is localized both in islets of Langherans and in the acini (see inset); the latest show a fine granular positivity in the absence of ductal reactivity; OM 400x. 
detected both in the exocrine and in the endocrine pancreas. Endocrine cells of the Langherans islets showed a strong cytoplasmic reactivity, whereas in acinar cells $\mathrm{T} \beta 10$ was mainly detected in granular deposits. No immunostaining was found in ductal cells nor inside the tubular lumen (Figure 7b).

\section{Liver}

No reactivity for $\mathrm{T} \beta 4$ and $\mathrm{T} \beta 10$ was observed in the liver samples. Data regarding immunoreactivity for both thymosins in the different rat organs are summarized in Table 1.

\section{Discussion}

The role of $\mathrm{T} \beta 4$ and $\mathrm{T} \beta 10$, the beta-thymosins expressed virtually in all mammalian tissues and cells, has not been completely clarified yet. Previous studies on their expression in the rat central nervous system evidenced that temporal and cellular patterns of their expression are different, suggesting that each beta-thymosin could play a specific physiological function during development and in adulthood..$^{32}$ Our study confirms the existence of marked differences in the distribution of $\mathrm{T} \beta 4$ and $\mathrm{T} \beta 10$ in the oro-gastro-intestinal tract of the adult rat. The most striking differences were found in the parotid and submandibular glands, in which T $\beta 4$ was absent whereas immunostaining for T $\beta 10$ was strong and diffuse. On the contrary, no reactivity for both beta-thymosins was detected in sublingual glands. These differences in beta-thymosin expression between different salivary glands confirm that each beta-thymosin probably plays a specific role in each salivary gland, irrespectively of their common embryogenesis.

No significant difference in $\mathrm{T} \beta 4$ and $\mathrm{T} \beta 10$ expression was present in the gastrointestinal tract: the absence of reactivity for both betathymosin in the oesofagus contrasts with the presence of both peptides in the enterocytes of the remaining gastrointestinal tract, confirming that a patchy distribution of these peptides should be expected, even in different parts of the same system.

The peculiar pattern for beta thymosins detected in pancreas deserves some considerations: T $\beta 10$ was strongly expressed both in the exocrine and in the endocrine cells, whereas $\mathrm{T} \beta 4$ reactivity was restricted to the Langerhans islet cells. These findings taken together clearly indicate the presence of a complex modulation in the expression of betathymosins inside the same organ, each thymosin playing different functions in different cell types, confirming the $\beta$-thymosin enigma. ${ }^{33}$

When data obtained in rat tissues were com- pared with immunoreactivity for $\mathrm{T} \beta 4$ and $\mathrm{T} \beta 10$ in human tissues, significant differences were evidenced, supporting the hypothesis that beta-thymosin expression in cells and tissues is species-specific. The most striking differences were found in liver specimens, characterized by the complete absence of both thymosins in rat, contrasting with the strong and diffuse reactivity for $\mathrm{T} \beta 4$ and $\mathrm{T} \beta 10$ previously reported in humans. ${ }^{34}$ However, which is the role of $\mathrm{T} \beta 4$ and $\mathrm{T} \beta 10$ in adult rat tissues? The detailed mechanisms of the action of T $\beta 4$ and $\mathrm{T} \beta 10$ in different mammalian cells and tissues are not fully understood, as well as the similarities and differences between these isoforms. ${ }^{35}$ Previous studies evidenced that activities of these two beta-thymosins are paradoxically different, $\mathrm{T} \beta 4$ promoting cell migration and angiogenesis, and T $\beta 10$ inhibiting angiogenesis. ${ }^{35}$ Opposing effects on angiogenesis are likely to be mediated via $\mathrm{T} \beta 4$ stimulation and $\mathrm{T} \beta 10$ inhibition of VEGF production. ${ }^{36}$

Moreover, in contrast to $\mathrm{T} \beta 4, \mathrm{~T} \beta 10$ has been shown to be a negative regulator of tumor development and progression. ${ }^{37}$ In short, T $\beta 4$ might promote cell survival by blocking apoptosis ${ }^{38}$ whereas $\mathrm{T} \beta 10$ might exert a proapoptotic activity, by accelerating apoptotic cell death. ${ }^{39}$ According with these data, we may speculate that the complex and pleiotropic expression of $\mathrm{T} \beta 4$ and $\mathrm{T} \beta 10$ here reported in different tissues and cell types might reflect different direct and indirect effects on the actin cytoskeleton, as well as modulation of signaling pathways that impact on different cellular functions. In particular, over-expression of T $\beta 4$ could be related to prevention of apoptosis by blocking early apoptotic signals ${ }^{40}$ whereas overexpression of $\mathrm{T} \beta 10$ might be related to its pro-apoptotic activity and to a down-regulation of cell growth ${ }^{35}$ and of angiogenesis. ${ }^{36}$

Finally, this study, one of the few in which the immunohistochemical expression pattern of $\mathrm{T} \beta 4$ and $\mathrm{T} \beta 10$ has been paralleled in the same tissues, evidenced that detailed mechanisms of the action of beta-thymosins in different cells and tissues are not fully understood, and show that our lack of knowledge is particularly evident regarding mature adult tissues, the vast majority of studies on the role of betathymosins having been carried out in fetal or tumoral tissues. Further studies exploring the molecular events that are associated with T $\beta 4$ and $\mathrm{T} \beta 10$ overexpression or down-regulation are required, in order to give a solution to the thymosin enigma.

\section{References}

\section{Hannappel E. $\beta$-Thymosins. Ann NY Acad Sci 2007;1112:21-37.}

2. Mannherz HG, Hannappel E. The $\beta$-thymosins: intracellular and extracellular activities of a versatile actin binding protein family. Cell Motil Cytoskeleton 2009;66:839-51.

3. Klein JJ, Goldstein AL, White A. Enhancement of in vivo incorporation of labeled precursors into DNA and total protein of mouse lymph nodes after administration of thymic extracts. Proc Natl Acad Sci USA 1965;53:812-7.

4. Hannappel E, Davoust S, Horecker BL. Isolation of peptides from calf thymus. Biochem Biophys Res Commun. 1982;104:266-71.

5. Low TL, Goldstein AL. Chemical characterization of thymosin $\beta_{4}$. J Biol Chem 1982;257:1000-6.

6. Hannappel E, Xu GJ, Morgan J, Hemstead J, Horecker BL. Thymosin $\beta 4$ : a ubiquitous peptide in rat and mouse tissues. Proc Natl Acad Sci USA 1982;79:2172-5.

7. Ericksson-Viitanen S, Ruggieri S, Natalini P, Horecker BL. Thymosin Beta 10, a new analogue of thymosin beta 4 in mammalian tissues. Arch Biochem Biophys 1983;225:407-13.

8. Yu FX, Lin SC, Morrison-Bogoard M, Atkinson MA, Yin HL. Thymosin beta 10 and thymosin beta 4 both actin sequestering proteins. J Biol Chem 1993;268:502-9.

9. Philp D, Goldstein AL, Kleinman HK. Thymosin T $\beta 4$ promotes angiogenesis, wound healing, and hair follicle development. Mech Ageing Dev 2004;125:113-5.

10. Bock-Marquette I, Saxena A, White MD, Dimaio JM, Srivastava D. Thymosin T $\beta 4$ activates integrin-linked kinase and promotes cardiac cell migration, survival and cardiac repair. Nature 2004;432:466-72.

11. Smart N, Risebro CA, Melville AA, Moses K, Schwartz RJ, Chien KR, et al. Thymosin T $\beta 4$ induces adult epicardial progenitor mobilization and neovascularization. Nature 2007;445:177-82.

12. Hall AK. Differential expression of thymosin genes in human tumors and in developing human kidney. Int $\mathrm{J}$ Cancer 1991;48:672-7.

13. Sun W, Kim H. Neurotrophic roles of the beta-thymosins in the development and regeneration of the nervous system. Ann NY Acad Sci 2007;1112:210-8.

14. Nemolato S, Cabras T, Fanari MU, Cau F, Fanni D, Gerosa C, et al. Immunoreactivity of Thymosin beta 4 in human foetal and adult genitourinary tract. Eur J Histochem 2010;54:e43.

15. Naylor PH, McClure JE, Spangelo BL, Low TL, Goldstein AL. Immunochemical studies on thymosin: radioimmunoassay of thymosin beta 4 . Immunopharmacology 1984 ; 7:9-16. 
16. Inzitari R, Cabras T, Pisano E, Fanali C, Manconi B, Scarano E, et al. HPLC-ESI-MS analysis of oral human fluid reveals that gingival crevicular fluidi s the main source of oral thymosin T $\beta 4$ and $\beta 10$. J Sep Sci 2009;32:57-63.

17. Badamchian M, Fagarasan M0, Danner RL, Suffredini AF, Damavandy H, Goldstein AL. Thymosin beta(4) reduces lethality and down regulates inflammatory mediators in endotoxin-induced septic shock. Int Immunopharmacol 2003;3:1225-33.

18. Bodendorf S, Born G, Hannappel E. Determination of thymosin beta 4 and protein in human wound fluid after abdominal surgery. Ann NY Acad Sci 2007;1112: 418-24.

19. Jo JO, Kim SR, Bae MK, Kang YJ, Ock MS, Kleinman HK, et al. Thymosin $\beta 4$ induces the expression of vascular endothelial growth factor (VEGF) in a hypoxiainducible factor (HIF)-1 -dependent manner. Biochim Biophys Acta 2010;1803: 1244-51.

20. Crockford D, Turjman N, Allan C, Angel J. Thymosin beta4: structure, function, and biological properties supporting current and future clinical applications. Ann NY Acad Sci 2010;1194:179-89.

21. Paulussen M, Landuyt B, Schoofs L, Luyten W, Arckens L. Thymosin beta 4 mRNA and peptide expression in phagocytic cells of different mouse tissues. Peptides 2009;30: 1822-32.

22. Gómez-Márquez J, Franco del Amo F, Carpintero P, Anadón R. High levels of mouse thymosin beta4 mRNA in differentiating P19 embryonic cells and during development of cardiovascular tissues. Biochim Biophys Acta 1996;1306:187-93.

23. Elitsur Y, Mutchnick MG, Sakr WA, Luk GD.
Thymosin alpha 1 and thymosin beta 4 modulate human colonic lamina propria lymphocyte function. Immunopharmacology 1990;20:89-96.

24. Nemolato S, Cabras T, Fanari MU, Cau F, Fraschini M, Manconi B, et al. Thymosin beta 4 expression in normal skin, colon mucosa and in tumor infiltrating mast cells. Eur J Histochem 2010;54:e3.

25. Kim YC, Kim BG, Lee JH. Thymosin $\beta 10$ expression driven by the human TERT promoter induces ovarian cancer-specific apoptosis through ROS production. PLoS One 2012;7:e35399.

26. Fehér LZ, Pocsay G, Krenács L, Zvara A, Bagdi E, Pocsay R, et al. Amplification of thymosin beta 10 and AKAP13 genes in metastatic and aggressive papillary thyroid carcinomas. Pathol Oncol Res 2012; 18:449-58.

27. Lee SM, Na YK, Hong HS, Jang EJ, Yoon GS, Park JY, et al. Hypomethylation of the thy$\operatorname{mosin} \beta(10)$ gene is not associated with its overexpression in non-small cell lung cancer. Mol Cells 2011;32:343-8.

28. Li M, Zhang Y, Zhai Q, Feurino LW, Fisher WE, Chen C, et al. Thymosin beta-10 is aberrantly expressed in pancreatic cancer and induces JNK activation. Cancer Invest 2009; 27:251-6.

29. Fanni D, Gerosa C, Nemolato S, Locci A, Marinelli V, Cabras T, et al. Thymosin beta 10 expression in developing human salivary glands. Early Hum Dev 2011;87:779-83.

30. Nemolato S, Messana I, Cabras T, Manconi B, Inzitari R, Fanali C, et al. Thymosin beta(4) and beta(10) levels in pre-term newborn oral cavity and foetal salivary glands evidence a switch of secretion during foetal development. PLoS One 2009; 4:e5109.
31. Nemolato S, Cabras T, Cau F, Fanari MU, Fanni D, Manconi B, et al. Different thymosin Beta 4 immunoreactivity in foetal and adult gastrointestinal tract. PLoS One 2010;5:e9111.

32. Gomez-Marquez J, Anadon R. The beta-thymosins, small actin-binding peptides widely expressed in the developing and adult cerebellum. Cerebellum 2002;1:95-102.

33. Sun HQ, Yin HL. The $\beta$-thymosin enigma. Ann NY Acad Sci 2007;1112:45-55.

34. Nemolato S, Van Eyken P, Cabras T, Cau F, Fanari MU, Locci A, et al. Expression pattern of thymosin beta 4 in the adult human liver. Eur J Histochem 2011;55:e25.

35. Sribenja S, Li M, Wongkham S, Wongkham C, Yao Q, Chen C. Advances in thymosin beta 10 research: differential expression, molecular mechanisms, and clinical implications in cancer and other conditions. Cancer Invest 2009; 27:1016-22.

36. Lee SH, Son MJ, Oh SH, Rho SB, Park K, Kim YJ, et al. Thymosin beta 10 inhibits angiogenesis and tumor growth by interfering with Ras function. Cancer Res 2005;65:137-48.

37. Freeman KW, Banyard J. Beta-thymosin in cancer: implications for the clinic. Future Oncol 2009;5:755-8.

38. Sosne G, Qui P, Goldstein AL, Wheater M. Biological activities of thymosin beta 4 defined by actives sites in short peptides sequences. FASEB J 2010;24:2144-51.

39. Hall AK. Thymosin beta-10 accelerates apoptosis. Cell Mol Biol Res 1995;41:16780.

40. Choi SY, Kim DK, Eun B, Kim K, Sun W, Kim H. Anti-apoptotic function of thymosin-beta in developing chick spinal motoneurons. Biochem Biophys Res Commun 2006;346:872-8. 